\title{
Formation and Evolution of Non-Metallic Inclusions in Calcium Treatment H13 Steel during Electroslag Remelting Process
}

\author{
Hao WANG, Jing LI, Chengbin SHI, Yongfeng Ql and Yuxiang DAI \\ State Key Laboratory of Advanced Metallurgy, University of Science and Technology Beijing, 30 Xueyuan Road, Haidian Dis- \\ trict, Beijing, 100083 P.R. China.
}

(Received on August 16, 2018; accepted on November 28, 2018)

\begin{abstract}
In the current study, the evolution of inclusions in $\mathrm{H} 13$ steel electrode with different Ca content refined through ESR process were analyzed, the formation and evolution of sulfide and oxide inclusions during ESR process was determined based on experiments and thermodynamic calculation. The results showed: The inclusions of remelted ingot were $\mathrm{Al}_{2} \mathrm{O}_{3}, \mathrm{CaO}-\mathrm{Al}_{2} \mathrm{O}_{3}-\mathrm{CaS}$ and $\mathrm{CaO}-\mathrm{Al}_{2} \mathrm{O}_{3}-\mathrm{MgO}-\mathrm{CaS}$, more than half of the total inclusions were smaller than $3 \mu \mathrm{m}$. The cleanliness and inclusions of remelted ingot had no difference with different $\mathrm{Ca}$ content in electrode. MnS inclusions in electrode precipitated while the solid fraction reached 0.98. MnS inclusions cannot precipitate due to the low level of $S$ content in remelted ingot and the decrease of $\mathrm{Mn}$ and $\mathrm{S}$ segregation on the front edge of solidified shell. The low-meltingtemperature inclusions were dissolved and disappeared completely before liquid metal droplets collected in the liquid metal pool. The different of local cooling intensity during $\mathrm{ESR}$ process and high $\mathrm{Al}_{2} \mathrm{O}_{3}$ content of liquid inclusion in molten pool promoted the formation of large amount of tiny $\mathrm{Al}_{2} \mathrm{O}_{3}$ inclusions in remelted ingot.
\end{abstract}

KEY WORDS: electroslag remelting; H13 steel; inclusion evolution; confocal microscope; thermodynamic calculation.

\section{Introduction}

Non-metallic inclusions have a significant detrimental influence on steel performance, such as toughness, strength and abrasive resistance. Electroslag Remelting (ESR) is a composite technique for metal or alloy refining and solidification structure control, which is used in many fields to produce high-end products or key components. The product has high purity, uniform composition, good mechanical properties and performance, near-final shape, controllable process, etc. ${ }^{1)}$ Most of the original inclusions in steel can be eliminated during ESR process and the distribution of inclusions in steel can be improved. ${ }^{2-4)}$ The type and size distribution of inclusions in steel will be modified fundamentally after ESR. ${ }^{5-7)}$ Therefore, it is crucial to clarify the evolution mechanism of inclusions during ESR process.

Calcium treatment is a very widely used countermeasure to modify the inclusions to liquid calcium aluminate inclusions in steel, which can improve the cleanliness of molten steel effectively and avoid nozzle clogging during continuous casting. ${ }^{8)}$ The type, morphology and size of inclusions after $\mathrm{Ca}$ treatment are related to the Ca content of steel. ${ }^{9)}$ In the production process of consumable electrode, Ca treatment is used commonly to obtain high purity consumable electrode, meanwhile, most of the inclusions can be controlled in the low-melting-temperature region $(<1873 \mathrm{~K})$

\footnotetext{
* Corresponding author: E-mail: lijing@ustb.edu.cn

DOI: https://doi.org/10.2355/isijinternational.ISIJINT-2018-537
}

after $\mathrm{Ca}$ treatment. It has been demonstrated that the types of inclusions in consumable electrode is one of the reason for affecting the inclusions in remelted ingot, because the original inclusions in electrode can hardly be eliminated completely through ESR process. ${ }^{10)}$ Several studies have focused on understanding the evolution mechanism of inclusions during the ESR process: Dong ${ }^{11}$ investigated the dissolution behavior for alumina-based inclusions in $\mathrm{CaF}_{2}-\mathrm{Al}_{2} \mathrm{O}_{3}-\mathrm{CaO}-\mathrm{MgO}-\mathrm{SiO}_{2}$ slag during ESR process. $\mathrm{Zhan}^{5)}$ found the protected ESR process removes $\mathrm{Al}_{2} \mathrm{O}_{3}-$ $\mathrm{SiO}_{2}-\mathrm{MnO}$ inclusions. $\mathrm{Liu}^{12}$ studied evolution of desulfurization and characterization of inclusions in dual alloy ingot processed by ESR. However, these previous studies did not clarify the formation and evolution mechanism of inclusions during ESR process.

In most cases, the inclusions with low-meltingtemperature exist in steel after $\mathrm{Ca}$ treatment. However, the removal mechanism of low-melting-temperature inclusions in consumable electrode during ESR process has not been investigated yet. In the current work, the formation and evolution of inclusions during ESR process was investigated by laboratory experiments and thermodynamic calculations. Three consumable electrodes with different $\mathrm{Ca}$ content were refined through ESR. A SEM equipped with an EDS was employed to characterize the inclusions, in addition, an ultrahigh-temperature confocal scanning laser microscope was adopted to observer the behavior of inclusion in solidliquid two-phase region. Thermodynamic calculation was performed simultaneously to clarify the elimination mecha- 
nism of oxide and sulfide inclusions during ESR process.

\section{Experimental Procedure}

The Protective-Gas-ESR device with a water-cooled copper of inner diameter of $170 \mathrm{~mm}$ was employed to remelt the consumable electrode. A H13 steel rod with a diameter of $80 \mathrm{~mm}$ was used as a consumable electrode. The premelted slag (4 kg for each trial, 60 mass pct $\mathrm{CaF}_{2}, 20$ mass pct $\mathrm{CaO}, 20$ mass pet $\mathrm{Al}_{2} \mathrm{O}_{3}$ ) was roasted at $923 \mathrm{~K}$ in chamber furnace for at least 10 hours before the P-ESR experiment. The operating current, voltage and outlet temperature of the mold cooling water was maintained at about $2400 \mathrm{~A}, 32 \mathrm{~V}$, and $303 \mathrm{~K}$ during the P-ESR process, respectively.

The steel sample of $12 \times 12 \times 12 \mathrm{~mm}$ were taken from the $2 / 3$ height of each ESR ingot, at the center, mid-radius and the edge position. Steel samples were mechanically grind by $\mathrm{SiC}$ sandpapers and polished by polishing cloth with diamond paste for analyzing inclusions. At least 20 inclusions of each sample were selected randomly to analyze the morphology and composition by SEM (FEI Quanta-250; FEI Corporation, Hillsboro, OR) equipped with EDS (XFlash 5030; Bruker, Germany). The size and composition distribution of inclusions were analyzed by INCA

Table 1. Main chemical composition of electrode (wt $\%)$.

\begin{tabular}{ccccccccc}
\hline $\mathrm{C}$ & $\mathrm{Si}$ & $\mathrm{Mn}$ & $\mathrm{P}$ & $\mathrm{Mo}$ & $\mathrm{Cr}$ & $\mathrm{V}$ & $\mathrm{Ni}$ & $\mathrm{N}$ \\
\hline 0.41 & 0.90 & 0.39 & 0.027 & 1.45 & 5.24 & 0.92 & 0.21 & 0.034 \\
\hline
\end{tabular}

Steel automatic detection system of non-metallic inclusions (EVO 18, ZEISS, Germany). The area of scanning was set as $5 \times 5 \mathrm{~mm}$. Steel powders were machined from each remelted ingot to measure contents of $\mathrm{Ca}, \mathrm{Als}, \mathrm{Mg}$, and $\mathrm{S}$, a rod of $5 \mathrm{~mm}$ in diameter and $40 \mathrm{~mm}$ length was cut from the same position of remelted ingot to test T.O. content. The main chemical composition of consumable electrode steel is listed in Table 1. The electrodes are numbered as $\mathrm{G}$, and the remelted ingots are numbered as $\mathrm{K}$. Ca, Als, S, $\mathrm{T} . \mathrm{O}$ and $\mathrm{Mg}$ content of each electrode and remelted ingot are listed in Table 2.

An ultrahigh-temperature confocal scanning laser microscope (CLSM, VL2000DX-SVF17SP, lasertec, Japan) was adopted to make the in situ observation of inclusions behavior in electrode during the melting process. The working principle and performance of CLSM have been described else by other researchers. ${ }^{13)}$ A steel sample (diameter of

Table 2. $\mathrm{Ca}, \mathrm{Als}, \mathrm{S}, \mathrm{T} . \mathrm{O}$ and $\mathrm{Mg}$ content of each electrode and remelted ingot (wt\%).

\begin{tabular}{cccccc}
\hline number & $\mathrm{Ca}$ & $\mathrm{Als}$ & $\mathrm{S}$ & $\mathrm{T}[\mathrm{O}]$ & $\mathrm{Mg}$ \\
\hline $\mathrm{G} 1$ & $<0.0005$ & 0.030 & 0.0100 & 0.0084 & $<0.001$ \\
$\mathrm{G} 2$ & 0.0005 & 0.033 & 0.0097 & 0.0094 & $<0.001$ \\
$\mathrm{G} 3$ & 0.0012 & 0.026 & 0.0100 & 0.0104 & $<0.001$ \\
$\mathrm{~K} 1$ & 0.0008 & 0.031 & 0.0023 & 0.0015 & $<0.001$ \\
$\mathrm{~K} 2$ & 0.0010 & 0.024 & 0.0022 & 0.0018 & $<0.001$ \\
$\mathrm{~K} 3$ & 0.0013 & 0.019 & 0.0021 & 0.0019 & $<0.001$
\end{tabular}
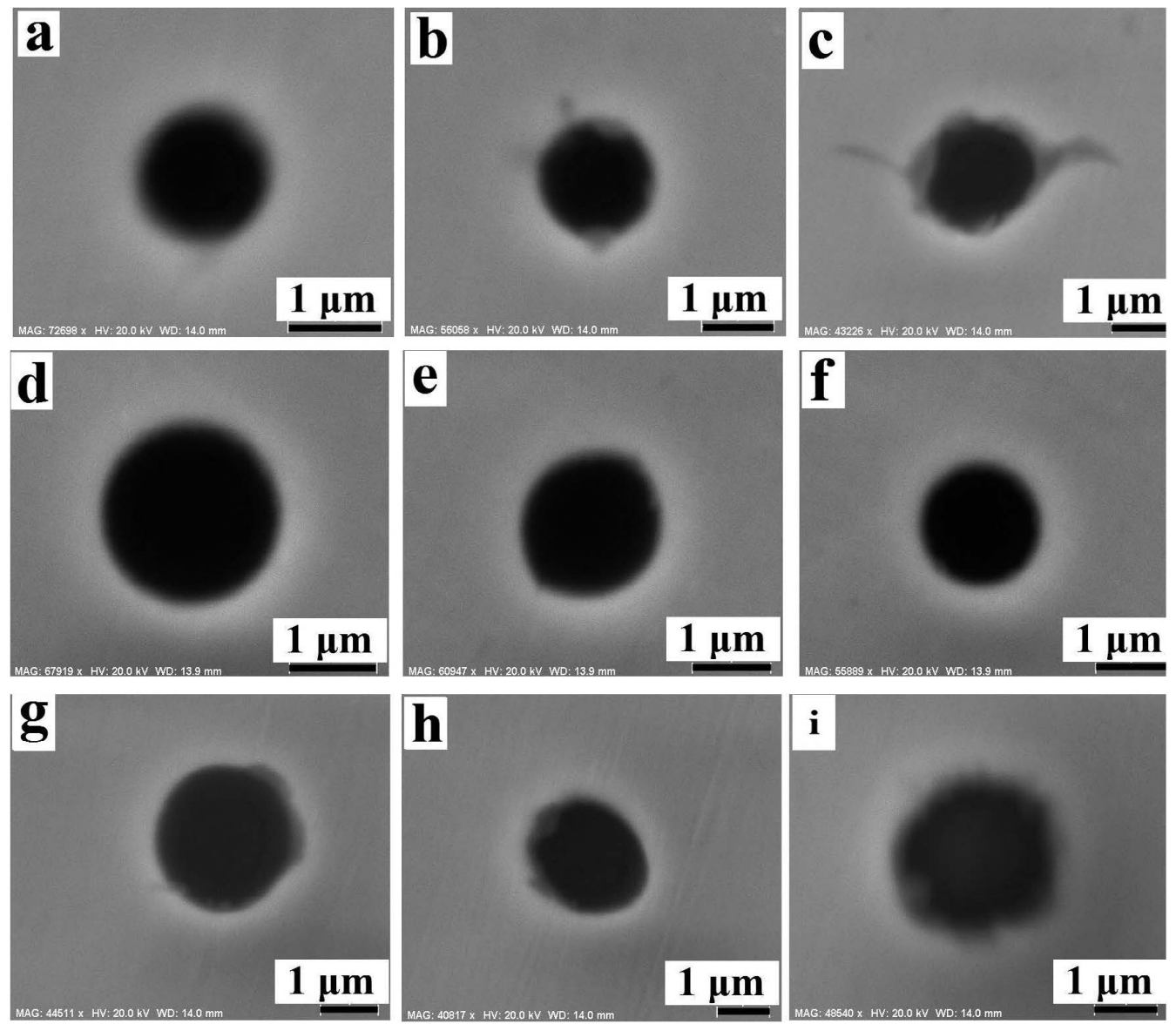

Fig. 1. Typical inclusion in consumable electrode (G1: a-c; G2: d-f; G3: g-i). 
$7.8 \mathrm{~mm}$, height of $2.5 \mathrm{~mm}$ ) was cut from the residual electrode tip after ESR process, the sample was placed into an alumina crucible (outer diameter of $9 \mathrm{~mm}$, inner diameter of $8 \mathrm{~mm}$, and height of $3 \mathrm{~mm}$ ) after polished. The gap between steel sample and crucible inwall should be to ensure is small, to avoid the microscope focusing is not clear due to the drop of the sample height caused by the melting of the sample surface during the experiment. The temperature of sample can be controlled effectively through temperature control program: Firstly, the temperature of sample raised to $1473 \mathrm{~K}$ at a rate of $200 \mathrm{~K} / \mathrm{min}$. In order to finely capture the behavior of inclusions at high temperatures, the power output is adjusted by manual control so that the temperature variation control range is about $\pm 1 \mathrm{~K} / \mathrm{s}$. The inclusions on the surface of the steel sample were observed under a microscope with a magnification of 1900 and recorded on the video at a rate of 4 frames per second.

\section{Results}

\subsection{Inclusions in Consumable Electrode}

Figure 1 shows the morphology of the inclusions in consumable electrodes. The typical inclusions observed in consumable electrodes are $\mathrm{CaO}-\mathrm{Al}_{2} \mathrm{O}_{3}-\mathrm{SiO}_{2}-\mathrm{MgO}$. MnS and $\mathrm{CrS}$ (grey structure in the figure) can be detected on the edge of the inclusions occasionally. There is no difference in the type of inclusions in the three electrodes steel.

Figure 2 demonstrates the composition distribution of oxide inclusions in each consumable electrode on phase diagram of $\mathrm{CaO}-\mathrm{Al}_{2} \mathrm{O}_{3}-\mathrm{SiO}_{2}-\mathrm{MgO}$, the phase diagram was calculated with FactSage 7.0 (FToxid database). The method of calculation is described as follows: 20 inclusions were selected to determine the composition distribution in each electrode. Firstly, the atomic percentage results of EDS detection of $\mathrm{Ca}, \mathrm{Si}, \mathrm{Al}$, and $\mathrm{Mg}$ were counted. Secondly, multiply the atomic percentages of the above four elements by the relative molecular mass. At last, the mass percentage of $\mathrm{CaO}, \mathrm{SiO}_{2}, \mathrm{Al}_{2} \mathrm{O}_{3}$ and $\mathrm{MgO}$ of inclusion were computed according to the products, and also the average values of each component were calculated. After the $\mathrm{MgO}$ content was determined, the $\mathrm{CaO}, \mathrm{SiO}_{2}$ and $\mathrm{Al}_{2} \mathrm{O}_{3}$ contents were normalized to 100 pct. Thereafter, the compositions of the observed inclusions by SEM-EDS in each electrode were plotted on phase diagram of $\mathrm{SiO}_{2}-\mathrm{Al}_{2} \mathrm{O}_{3}-\mathrm{CaO}-(\mathrm{MgO})$ as shown in Figs. 2(a) through 2(c), respectively. The average composition of inclusions in each electrode is presented in Table 3. As can be seen in Fig. 2(a), some of the inclusions are located out of $1873 \mathrm{~K}$ low-melting-temperature region. All the inclusions in electrodes G2 and G3 are located in the liquid region, as presented in Figs. 2(b) and 2(c). The distribution of inclusions on phase diagram is more concentrated in $1673 \mathrm{~K}$ low-melting-temperature region as shown in Fig. 2(c), which indicates the melting temperature of oxide inclusions is lower with the increasing of $\mathrm{Ca}$ content of steel.

\subsection{Inclusions in Remelted Ingots}

The size distribution of each type of inclusions in remelted ingots are shown in Fig. 3. Due to the little difference between the size distribution of each type of inclusions in different position, the statistical results of mid-radius position is only presented for concision. The oxide inclusions
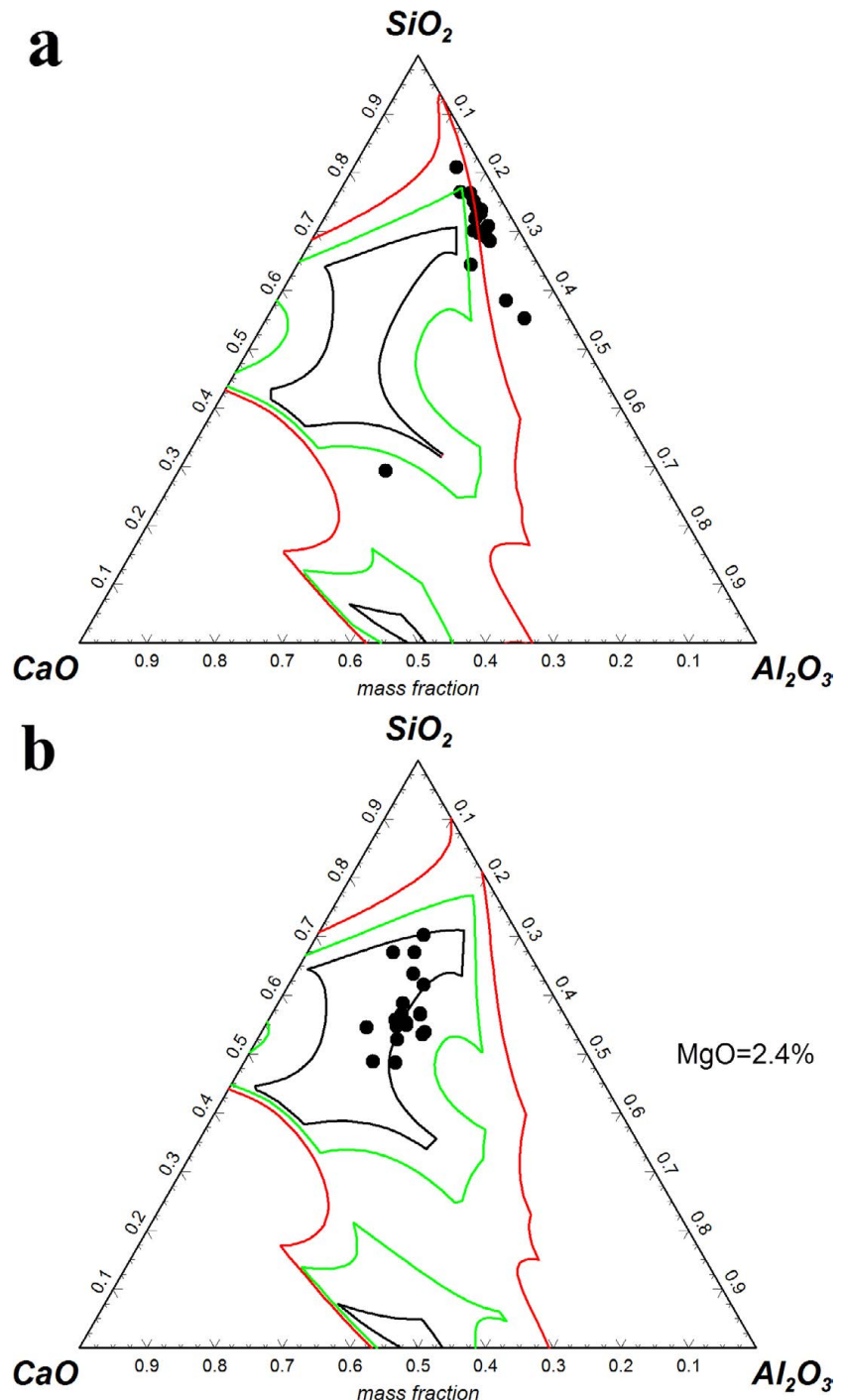

$\mathrm{SiO}_{2}$

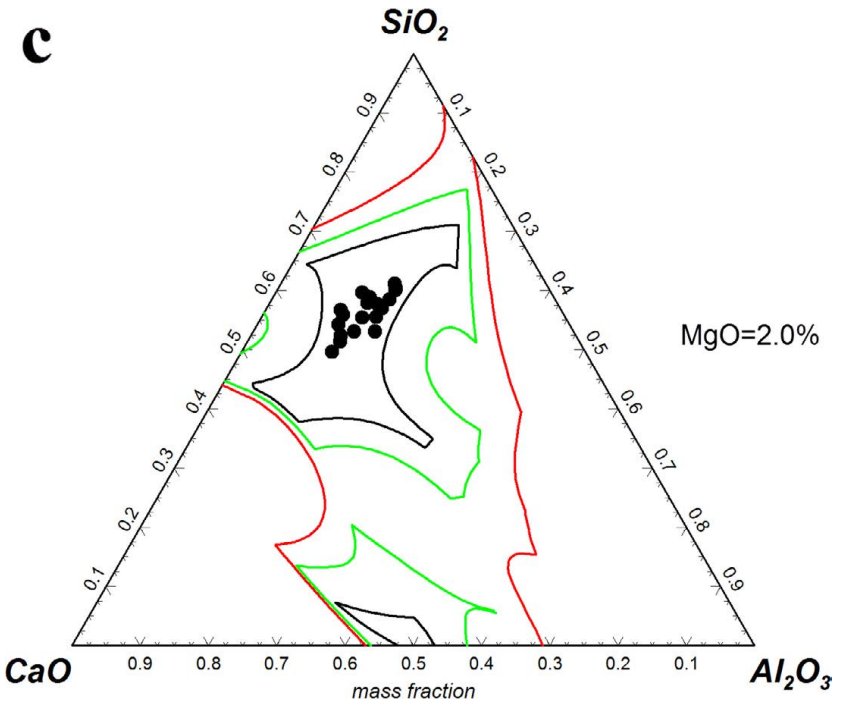

Fig. 2. Composition distributions of oxide inclusions in consumable electrode on phase diagram (red line $<1873 \mathrm{~K}$, green line $<1773 \mathrm{~K}$, black line $<1673 \mathrm{~K}, \mathrm{G1}$ : a; G2: b; G3: c). (Online version in color.)

in remelted ingots are $\mathrm{Al}_{2} \mathrm{O}_{3}, \mathrm{CaO}-\mathrm{Al}_{2} \mathrm{O}_{3}$ and $\mathrm{CaO}-\mathrm{MgO}-$ $\mathrm{Al}_{2} \mathrm{O}_{3}$. As can be seen in Fig. 3, most $\mathrm{Al}_{2} \mathrm{O}_{3}$ inclusions are smaller than $3 \mu \mathrm{m}$. The size of inclusions contained $\mathrm{Ca}$ is much bigger than $\mathrm{Al}_{2} \mathrm{O}_{3}$, and $\mathrm{Ca}$-containing inclusions 
Table 3. The average composition of inclusion in each electrode (wt \%).

\begin{tabular}{ccccc}
\hline number & $\mathrm{SiO}_{2}$ & $\mathrm{Al}_{2} \mathrm{O}_{3}$ & $\mathrm{CaO}$ & $\mathrm{MgO}$ \\
\hline $\mathrm{G} 1$ & $65.2391 \%$ & $27.9547 \%$ & $6.8062 \%$ & - \\
$\mathrm{G} 2$ & $55.2878 \%$ & $14.6721 \%$ & $28.0359 \%$ & $2.0042 \%$ \\
$\mathrm{G} 3$ & $56.0320 \%$ & $18.9408 \%$ & $22.6093 \%$ & $2.4178 \%$ \\
\hline
\end{tabular}

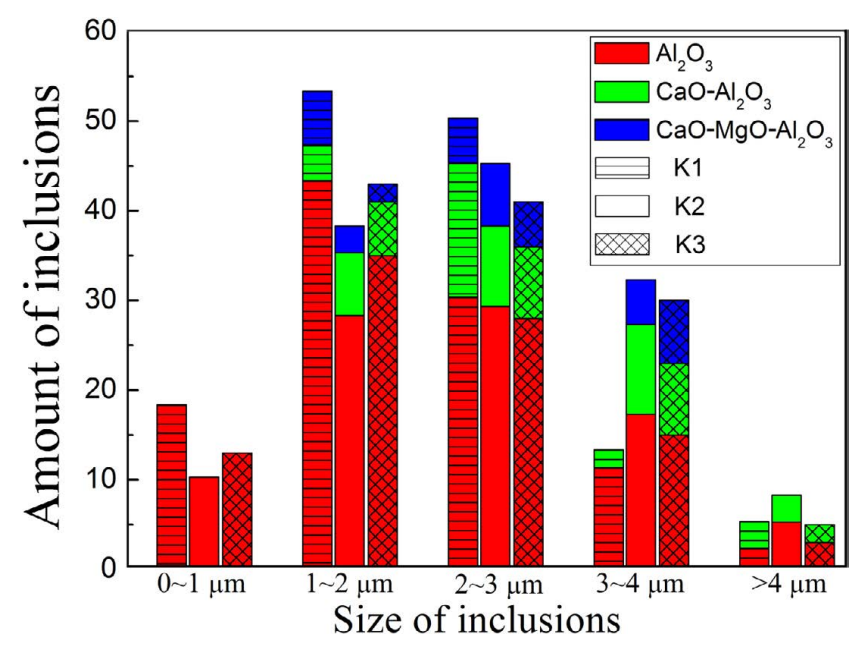

Fig. 3. Size distribution of each type oxide inclusion in remelted ingots. (Online version in color.)

smaller than $1 \mu \mathrm{m}$ were not detected. The statistical results of the three remelted ingots are similar. It indicates that the difference in $\mathrm{Ca}$ content of electrode have almost no effect on the size distribution of inclusions in remelted ingots.

The proportion of each type oxide inclusion in remelted ingots at different position is shown in Fig. 4. $\mathrm{Al}_{2} \mathrm{O}_{3}$ inclusions take up over $70 \%$ of the total inclusions at the center position and the mid-radius position in all the remelted ingots. The proportion of oxide inclusion at the edge of remelted ingot shows a difference result: The proportion of Ca-containing inclusions increase and $\mathrm{Al}_{2} \mathrm{O}_{3}$ inclusions take up lower than $60 \%$.

$\mathrm{Al}_{2} \mathrm{O}_{3}$ inclusions were not detected in consumable electrodes, surely the $\mathrm{Al}_{2} \mathrm{O}_{3}$ inclusions were formed during the ESR process. It can be seen in Fig. 5 that the size of $\mathrm{Al}_{2} \mathrm{O}_{3}$ inclusions are very tiny, some of the size of $\mathrm{Al}_{2} \mathrm{O}_{3}$ inclusions are smaller than $1 \mu \mathrm{m}$. Compared with the cluster-like $\mathrm{Al}_{2} \mathrm{O}_{3}$ inclusions that are easily generated by traditional metallurgy process, ${ }^{14,15)}$ the $\mathrm{Al}_{2} \mathrm{O}_{3}$ inclusions in remelted ingot are tiny and dispersed, and no aggregated cluster-like $\mathrm{Al}_{2} \mathrm{O}_{3}$ inclusions were detected in remelted ingots.

Figure 6 presents the map scanning of Ca-containing complex inclusions in remelted ingots. As can be seen in Fig. 6, $\mathrm{MgO}-\mathrm{Al}_{2} \mathrm{O}_{3}$ or $\mathrm{Al}_{2} \mathrm{O}_{3}$ inclusions act as the nuclei of heterogeneous nucleation, and $\mathrm{CaS}$ precipitated on the surfaces of $\mathrm{CaO}-\mathrm{Al}_{2} \mathrm{O}_{3}-\mathrm{MgO}$ inclusions. Most of $\mathrm{Ca}-$ containing complex inclusions are associated with $\mathrm{CaS}$. The inclusions in the form of $\mathrm{CaO}-\mathrm{Al}_{2} \mathrm{O}_{3}-\mathrm{SiO}_{2}-\mathrm{MgO}$ accompanied by $\mathrm{MnS}$ or $\mathrm{CrS}$ inclusions in the embedded form, which were the dominating inclusions in the electrodes, were not observed in each remelted ingot. It indicates that the $\mathrm{MnS}$ and $\mathrm{CrS}$ inclusions in consumable electrode were totally eliminated during ESR process.

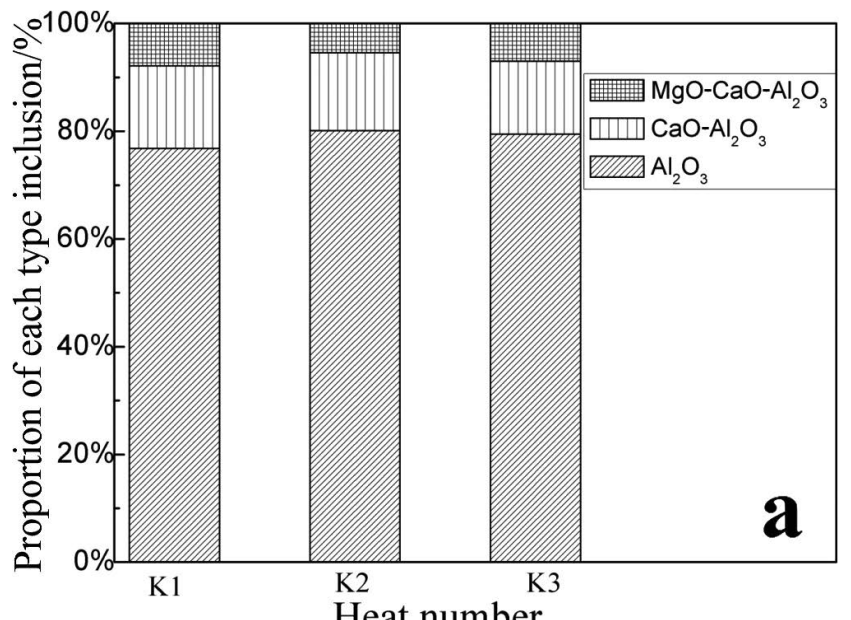

Heat number
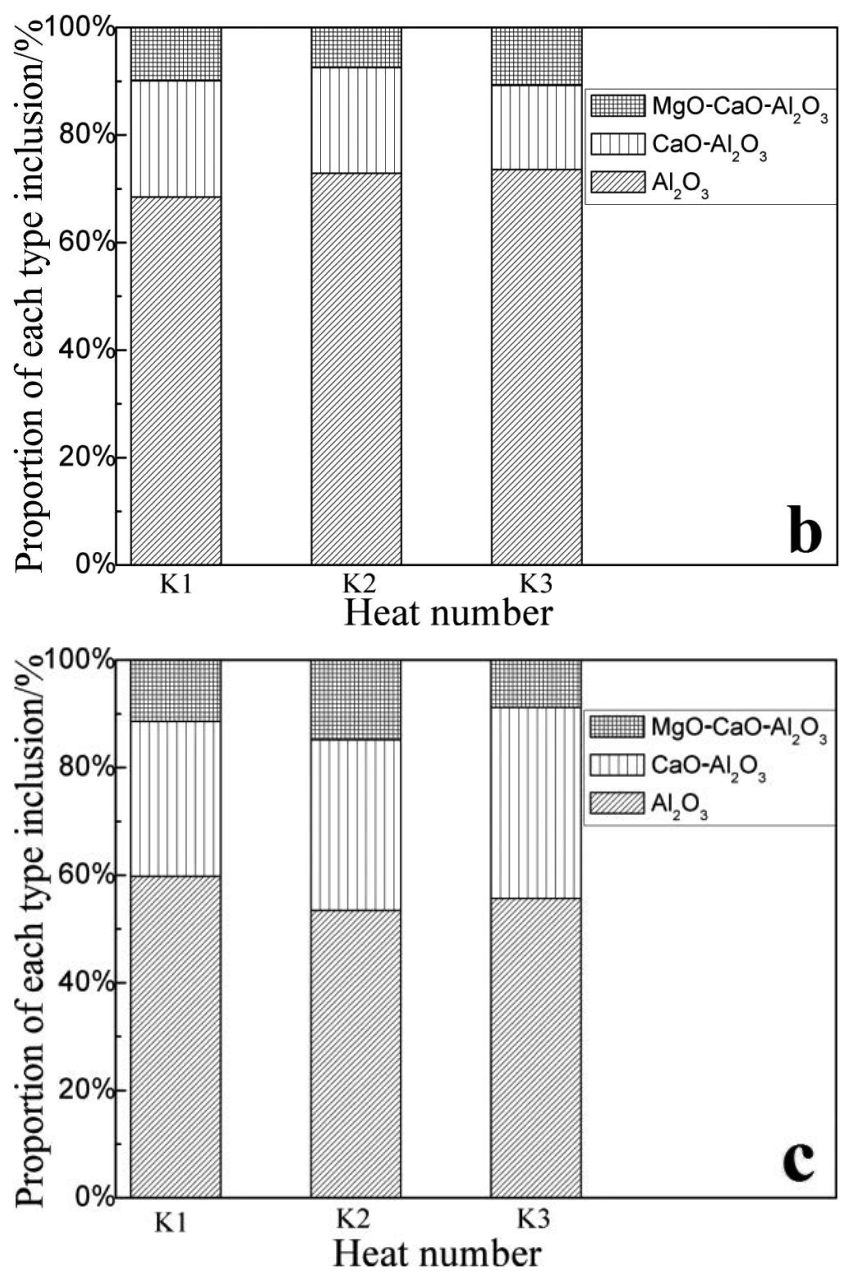

Fig. 4. Proportion of each type oxide inclusion in remelted ingots (a: the center position samples; b: the mid-radius position samples c: the edge position samples).

The mechanism of $\mathrm{MgO}-\mathrm{Al}_{2} \mathrm{O}_{3}$ inclusion modification during $\mathrm{Ca}$ treatment has been illustrated by many researchers: ${ }^{16-19)} \mathrm{MgO}-\mathrm{Al}_{2} \mathrm{O}_{3}$ inclusions react with dissolved calcium $[\mathrm{Ca}]$ on their surfaces, a $\mathrm{CaO}-\mathrm{MgO}-\mathrm{Al}_{2} \mathrm{O}_{3}$ layer generates on the surface of the $\mathrm{MgO}-\mathrm{Al}_{2} \mathrm{O}_{3}$ inclusion. The dissolved calcium in the molten steel transfer to the surface of $\mathrm{CaO}-\mathrm{MgO}-\mathrm{Al}_{2} \mathrm{O}_{3}$ layer while $[\mathrm{Mg}]$ created by the reaction transfers from the surface into the molten steel. Finally, $\mathrm{MgO}-\mathrm{Al}_{2} \mathrm{O}_{3}$ inclusions are modified to $\mathrm{CaO}-$ $\mathrm{MgO}-\mathrm{Al}_{2} \mathrm{O}_{3}$ inclusions with a small fraction of $\mathrm{MgO}$ and homogeneous chemical compositions. As shown in Fig. 6, 


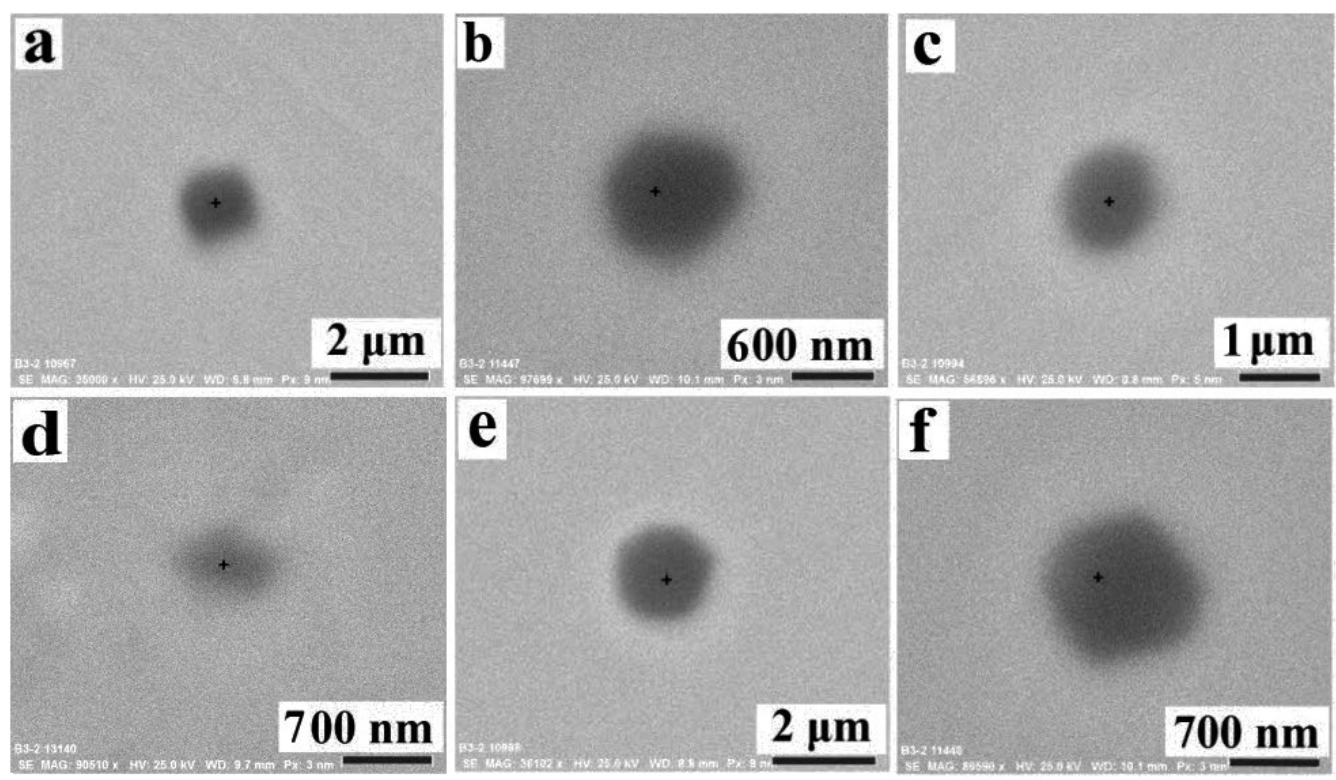

Fig. 5. $\mathrm{Al}_{2} \mathrm{O}_{3}$ inclusion of remelted ingots (K1: a,b; K2: c,d; K3: e,f).

a $\mathrm{MgO}-\mathrm{Al}_{2} \mathrm{O}_{3}$ lump in complex inclusions can be observed in each remelted ingot. It indicates that the inclusions of remelted ingot failed to form the $\mathrm{CaO}-\mathrm{MgO}-\mathrm{Al}_{2} \mathrm{O}_{3}$ with homogeneous composition. This phenomenon can come to two conclusions: (i) $\mathrm{MgO}-\mathrm{Al}_{2} \mathrm{O}_{3}$ and $\mathrm{Al}_{2} \mathrm{O}_{3}$ inclusions were formed firstly during ESR process, (ii) $\mathrm{MgO}-\mathrm{Al}_{2} \mathrm{O}_{3}$ and $\mathrm{Al}_{2} \mathrm{O}_{3}$ inclusions were modified by $\mathrm{Ca}$ in the liquid melt pool. It is speculated that the rapid solidification of liquid melt pool lead to the insufficient modification of Cacontaining complex inclusions.

\section{Discussions}

\subsection{Elimination of Sulfide Inclusions during ESR Pro- cess}

To reveal the elimination of sulfide inclusions during ESR process, the thermodynamic condition of MnS formation and effects of ESR process on precipitation of $\mathrm{MnS}$ are discussed. The chemical content of remelted ingot K2 is selected. The dissolution reactions of $\mathrm{MnS}$ is given in Eq. (1): ${ }^{20)}$

$$
[\mathrm{Mn}]+[\mathrm{S}]=(\mathrm{MnS}), \lg K=8629.58 / T-4.7467
$$

where $K$ is the reaction equilibrium constants of $\mathrm{MnS}$ inclusions, $T$ is the temperature of molten steel, $K$ can be expressed as:

$$
\lg K=\lg \frac{a_{[\mathrm{Mn}]} \cdot a_{[\mathrm{S}]}}{a_{(\mathrm{MnS})}}
$$

The activity of MnS is assumed to be unity according to its low solubility. Equation (2) can be derived as Eq. (3):

$$
\begin{aligned}
& \lg \frac{a_{[\mathrm{Mn}]} \cdot a_{[\mathrm{S}]}}{a_{(\mathrm{MnS})}}=\lg a_{[\mathrm{Mn}]}+\lg a_{[\mathrm{S}]} \\
& =\lg f_{\mathrm{Mn}}+\lg f_{\mathrm{S}}+\lg [\% \mathrm{Mn}][\% \mathrm{~S}]
\end{aligned}
$$

where $f_{\mathrm{Mn}}$ and $f_{\mathrm{S}}$ are the activity coefficient of $\mathrm{Mn}$ and $\mathrm{S}$, the activity coefficient is calculated by Eq. (4). ${ }^{21)} e_{i}^{j}$ means the first order interaction coefficient of elements $j$ to $i$ relative to dilute solution. It should be pointed out that only the first order interaction coefficients are taken into account to calculate the activity coefficient of $\mathrm{Mn}$ and $\mathrm{S}$ in present work. The first-order interaction parameters are listed in Table $\mathbf{4}^{22,23)}$

$$
\lg f_{i}=\sum e_{i}^{j}[\% j]
$$

The stability diagram of $\mathrm{MnS}$ precipitation can be obtained according to the related parameters. The liquidus and solidus temperatures calculated by the corresponding formulas reported in literature ${ }^{24)}$ are $1750 \mathrm{~K}$ and $1614 \mathrm{~K}$. As shown in Fig. 7, MnS is unable to precipitate in liquid steel above the liquidus and solidus temperatures.

Because the temperature of liquid metal film of electrode tip is closed to the liquidus temperature of electrode steel, $\mathrm{MnS}$ is dissociated into [Mn] and [S] at the tip of electrode during ESR process according to Fig. 7. It is concluded that $\mathrm{MnS}$ would not precipitate in liquid steel both in electrode and remelted ingot, but the calculation leaved out of consideration of the segregation during solidification of steel. Thus, the formation of $\mathrm{MnS}$ with taking account of micro segregation was further calculated. The micro segregation of $\mathrm{Mn}$ and $\mathrm{S}$ in molten steel during solidification was calculated by using Won-Thomas model: ${ }^{25}$

$$
\omega([i])_{\mathrm{L}}=\omega([i])_{0}\left[1-(1-\beta k) \cdot f_{S}\right]^{(k-1) /(1-\beta k)}
$$

where $\omega([i])_{\mathrm{L}}$ is the mass fraction (\%) of solute in liquid steel during solidification, $\omega([i])_{0}$ is the initial mass fraction $(\%)$ of solute in liquid steel before solidification, $f_{\mathrm{S}}$ is the solid fraction, $k$ is the equilibrium distribution coefficient of solute between liquid and solid phase. $\beta$ is a back-diffusion parameter:

$$
\beta=2 \alpha^{+}\left[1-\exp \left(-\frac{1}{\alpha^{+}}\right)\right]-\exp \left(-\frac{1}{2 \alpha^{+}}\right)
$$

where $\alpha^{+}$is the columnar structure model, the formula can be expressed as:

$$
\alpha^{+}=2\left(\alpha_{i}+\alpha^{C}\right), \alpha_{i}=\frac{4 \mathrm{D}_{s} t_{\mathrm{f}}}{\lambda_{\mathrm{s}}^{2}}
$$



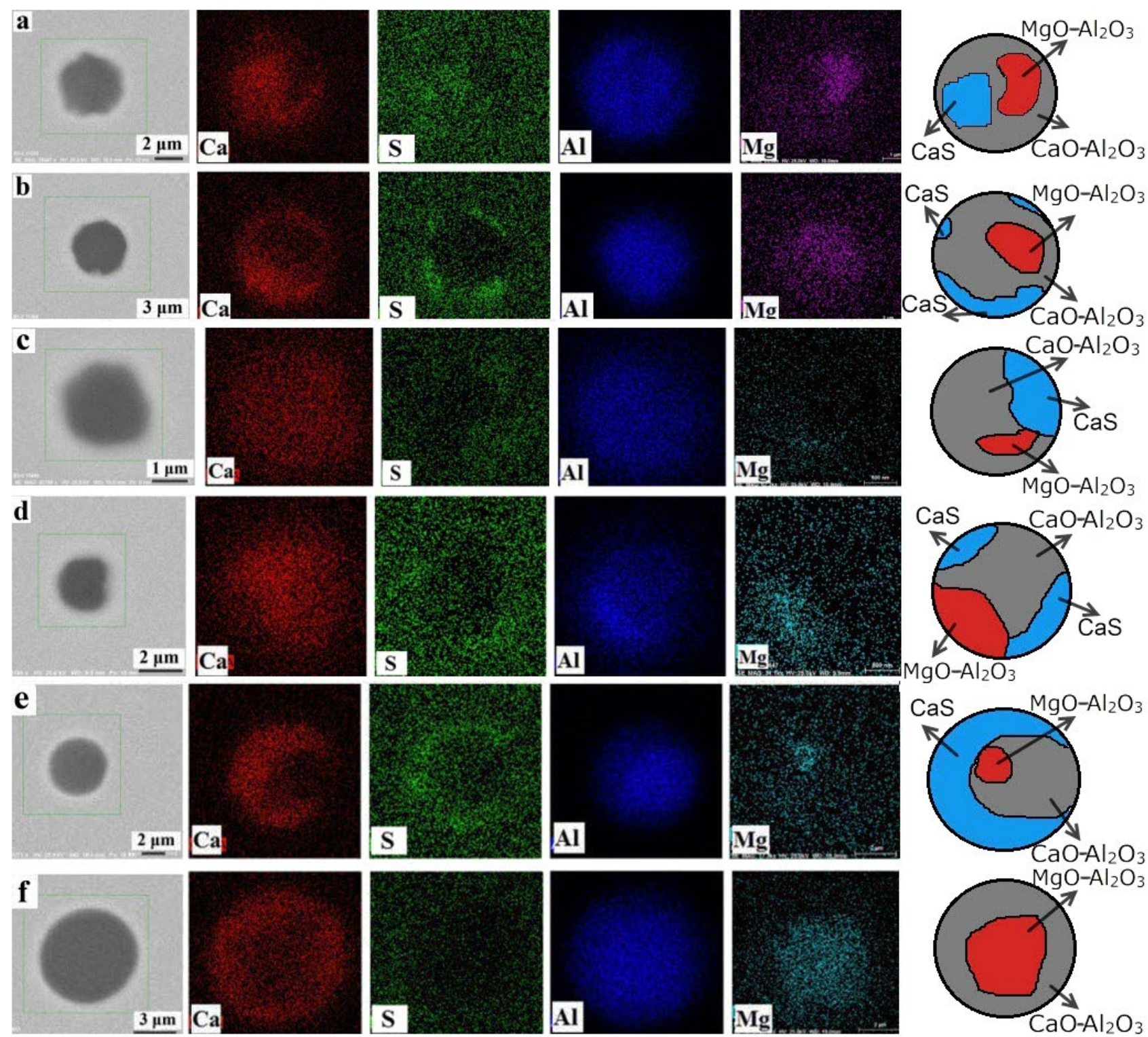

Fig. 6. Map scanning of Ca-containing complex inclusions in remelted ingots (K1: a,b; K2: c,d; K3: e,f). (Online version in color.)

Table 4. Interaction coefficients of $\mathrm{Mn}, \mathrm{S}, \mathrm{Si}$ and $\mathrm{Al}$ in molten steel at $1873 \mathrm{~K}$.

\begin{tabular}{ccccccccccccccccccc}
\hline$e_{i}^{j}$ & $\mathrm{C}$ & $\mathrm{Si}$ & $\mathrm{V}$ & $\mathrm{N}$ & $\mathrm{O}$ & $\mathrm{S}$ & $\mathrm{Al}$ & $\mathrm{Cr}$ & $\mathrm{Mn}$ & $\mathrm{Mo}$ & $\mathrm{P}$ & $\mathrm{Mg}$ & $\mathrm{Ca}$ \\
\hline $\mathrm{S}$ & 0.11 & 0.063 & -0.016 & 0.01 & -0.27 & -0.028 & 0.035 & -0.011 & -0.026 & 0.0027 & 0.029 & - & - \\
$\mathrm{Mn}$ & -0.07 & -0.0002 & - & -0.091 & -0.083 & -0.048 & - & 0.0036 & 0 & - & -0.0035 & - & - \\
$\mathrm{Si}$ & 0.18 & 0.11 & 0.025 & 0.09 & -0.23 & 0.056 & 0.058 & -0.0003 & 0.002 & - & 0.11 & - & -0.067 \\
$\mathrm{Al}$ & 0.091 & 0.056 & - & -0.058 & -6.6 & 0.03 & 0.045 & 0.012 & 0.035 & - & 0.033 & -0.13 & -0.047 \\
\hline
\end{tabular}

where $\alpha_{i}$ is a Fourier number for solute element $i, \alpha_{\mathrm{C}}$ is a constant value $0.1, D_{S}$ is the diffusion coefficient $\left(\mathrm{cm}^{2} \cdot \mathrm{s}^{-1}\right)$ of solute in solid phase, $\lambda_{\mathrm{S}}$ is the secondary dendrite arm spacing $(\mathrm{mm}), t_{\mathrm{f}}$ is the local solidification time (min):

$$
t_{\mathrm{f}}=\frac{T_{\mathrm{L}}-T_{\mathrm{S}}}{R_{\mathrm{C}}}
$$

where $R_{\mathrm{C}}$ is the cooling rate $\left(\mathrm{K} \cdot \mathrm{min}^{-1}\right)$. In consideration of steel carbon contents, the secondary dendrite arm spacing can be expressed as:

$$
\lambda_{\mathrm{S}}=143.9 \times R_{\mathrm{C}}^{-0.3616} \cdot \omega([\mathrm{C}])^{(0.5501-1.996 \omega([\mathrm{C}]))}
$$

In a region where both solid and liquid coexist in a dendrite cell, the temperature at the interface between the solid and liquid phases can be given by: ${ }^{26)}$

$$
T=T_{0}-\frac{T_{0}-T_{\mathrm{L}}}{1-f_{s} \frac{T_{\mathrm{L}}-T_{\mathrm{S}}}{T_{0}-T_{\mathrm{S}}}}
$$

where $T_{0}$ represents the melting point of pure iron $(1809 \mathrm{~K})$. The activity coefficients of $\mathrm{Mn}$ and $\mathrm{S}$ can dramatically 


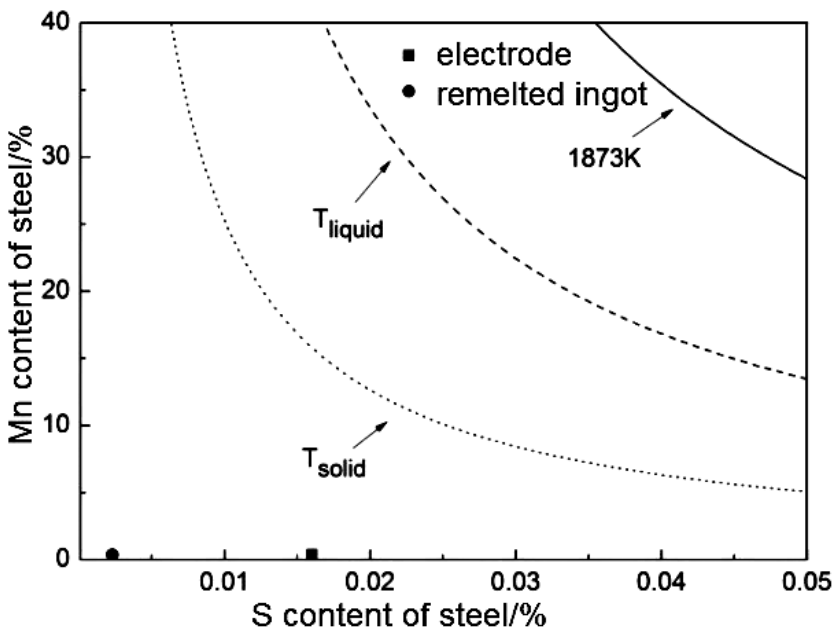

Fig. 7. Equilibrium diagram of $\mathrm{MnS}$ precipitation.

affect the precipitation of $\mathrm{MnS}$ during solidification. As the temperature decreases during solidification, the activity coefficient of element changes with the temperature. The variations of activity coefficient at solid liquid interface temperature can be obtained by: ${ }^{27)}$

$$
\begin{aligned}
\lg f^{\prime}{ }_{\mathrm{Mn}} & =\left(2538 / T_{\mathrm{S}-\mathrm{L}}-0.355\right) \lg f_{\mathrm{Mn}(1873 \mathrm{~K})} \ldots \ldots .( \\
\lg {f^{\prime}}_{\mathrm{S}} & =\left(2538 / T_{\mathrm{S}-\mathrm{L}}-0.355\right) \lg f_{\mathrm{S}(1873 \mathrm{~K})} \ldots \ldots . .(12)
\end{aligned}
$$

The equilibrium distribution coefficients and diffusion coefficients of $\mathrm{Mn}$ and $\mathrm{S}$ are given in Table $5 .{ }^{28)}$

In the current calculation, the consumable electrode $\mathrm{G} 2$ and remelted ingot $\mathrm{K} 2$ were selected as the object of calculation. The average values of secondary dendrite arm spacing of electrode $\mathrm{G} 2$ and remelted ingot $\mathrm{K} 2$ are $134 \mu \mathrm{m}$ and $81 \mu \mathrm{m}$, respectively. The $\mathrm{Mn}$ and $\mathrm{S}$ content in consumable electrode $\mathrm{G} 2$ are $0.39 \%$ and $0.0097 \%$ respectively and the $\mathrm{Mn}$ and $\mathrm{S}$ content in remelted ingot $\mathrm{K} 2$ are $0.39 \%$ and $0.0022 \%$ respectively. The actual solubility product of $\mathrm{Mn}$ and $\mathrm{S}$ changing with solid fraction in electrode and remelted ingot were calculated by Eqs. (5)-(12). The temperature at each solid fraction during solidification process and the corresponding equilibrium solubility product of $\mathrm{Mn}$ and $\mathrm{S}$ are also calculated, the results are shown in Fig. 8.

As can be seen in Fig. 8(a), the actual $w([\mathrm{Mn}]) \cdot w([\mathrm{~S}])$ intersects with equilibrium $\mathrm{w}([\mathrm{Mn}]) \cdot \mathrm{w}([\mathrm{S}])$ of the consumable electrode at the solid fraction of 0.98 during the solidification process. It indicates that $\mathrm{MnS}$ start to precipitate when solid fraction reaches 0.98 . There is no intersections occur between the actual $w([\mathrm{Mn}]) \cdot w([\mathrm{~S}])$ and equilibrium $\mathrm{w}([\mathrm{Mn}]) \cdot \mathrm{w}([\mathrm{S}])$ of the remelted ingot during the solidification process, as shown in Fig. 8(b). It indicates that $\mathrm{MnS}$ cannot precipitate in the liquid metal pool during the solidification of ESR process. The calculated results agree well with the experiment results. According the calculation results above, it is concluded that the formation of $\mathrm{MnS}$ inclusions in the electrode is due to that the solubility product of $\mathrm{Mn}$ and $\mathrm{S}$ exceed the equilibrium solubility product for $\mathrm{MnS}$ formation, which is caused by the micro segregation of $\mathrm{Mn}$ and $\mathrm{S}$ during solidification process. The segregation degree of $\mathrm{Mn}$ and $\mathrm{S}$ of electrode are larger than remelted ingot due to the solidification rate of electrode is slower than remelted ingot. MnS cannot form in the
Table 5. Distribution coefficient and diffusion coefficient of elements in liquid and solid phases.

\begin{tabular}{ccc}
\hline Element & $\mathrm{k}^{\gamma / \mathrm{L}}$ & $\mathrm{D}^{\gamma / \mathrm{L}} \times 10^{4} /\left(\mu \mathrm{m}^{2} \cdot \mathrm{s}^{-1}\right)$ \\
\hline $\mathrm{Mn}$ & 0.785 & $0.055 \exp [-249366 /(\mathrm{RT})]$ \\
$\mathrm{S}$ & 0.035 & $2.4 \exp [-223426 /(\mathrm{RT})]$ \\
\hline
\end{tabular}
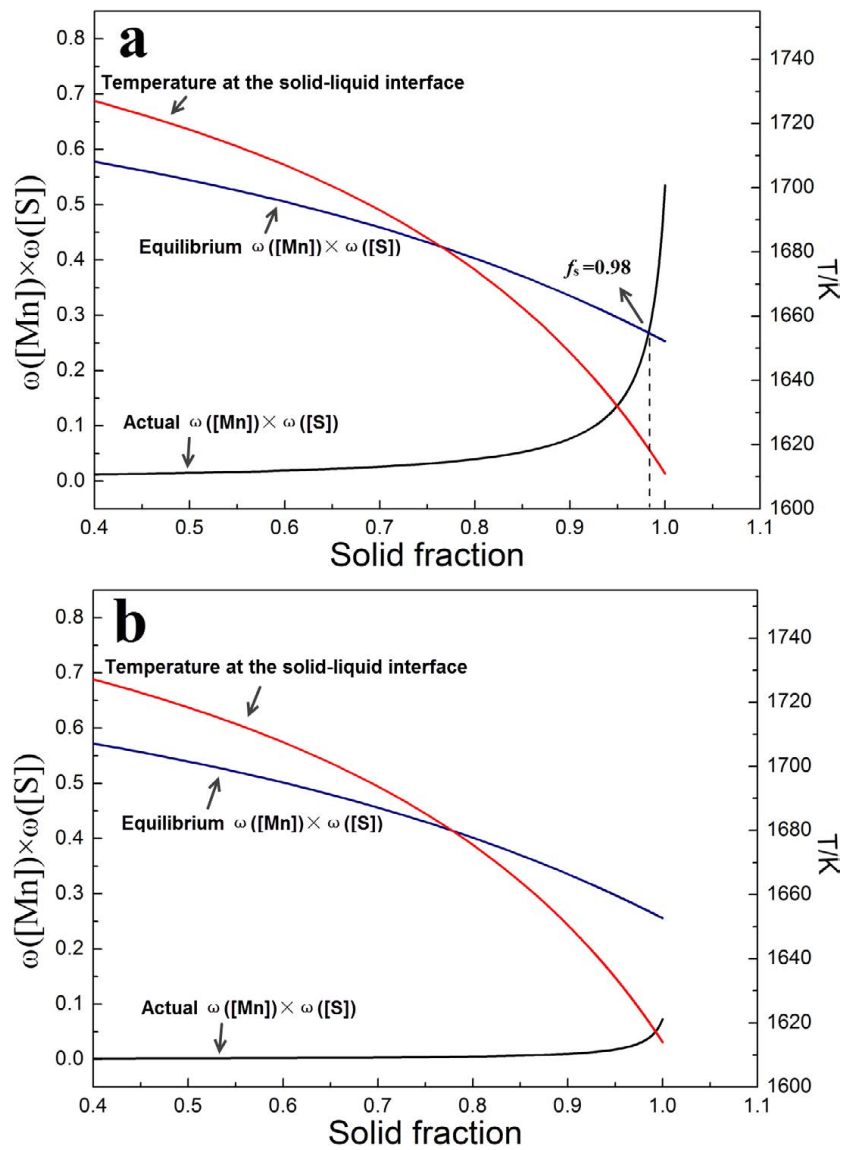

Fig. 8. Relationship between equilibrium $w([\mathrm{Mn}]) \cdot w([\mathrm{~S}])$ and actual $w([\mathrm{Mn}]) \cdot w([\mathrm{~S}])$ (electrode: a; remelted ingot: $\mathrm{b}$ ). (Online version in color.)

remelted ingot during the ESR process on account of the rapid solidification of liquid metal pool and gradualness solidification of remelted ingot, and the segregation degree of solutes reduced at the front of solidification.

\subsection{Evolution of Oxide Inclusions during ESR Process}

The evolution mechanism of low-melting-temperature inclusions of consumable electrode during ESR process was investigated by CLSM. The evolution of $\mathrm{CaO}-\mathrm{Al}_{2} \mathrm{O}_{3}-$ $\mathrm{MgO}-\mathrm{SiO}_{2}$ inclusion during the process of heating up is shown in Fig. 9. In Figs. 9(a), 9(b) and 9(c), $\mathrm{CaO}-\mathrm{Al}_{2} \mathrm{O}_{3}-$ $\mathrm{MgO}-\mathrm{SiO}_{2}$ inclusion remain unchanged at the temperature of $1400.2-1420.6^{\circ} \mathrm{C}$. There is a small "white spot" can be observed in the center of the inclusion in Fig. 9(d), it indicates the inclusions begin to melt to liquid state and the matrix of steel begin to be exposed with the increasing of temperature. This phenomenon becomes more apparent with the increasing of temperature. As shown through Figs. 9(e) to 9 (h) $\left(1430.0-1442.3^{\circ} \mathrm{C}\right)$, the "white spot" expand further until the inclusion is completely dissolved into steel finally. In Fig. 9(i), there is only one pit remains on the sample 

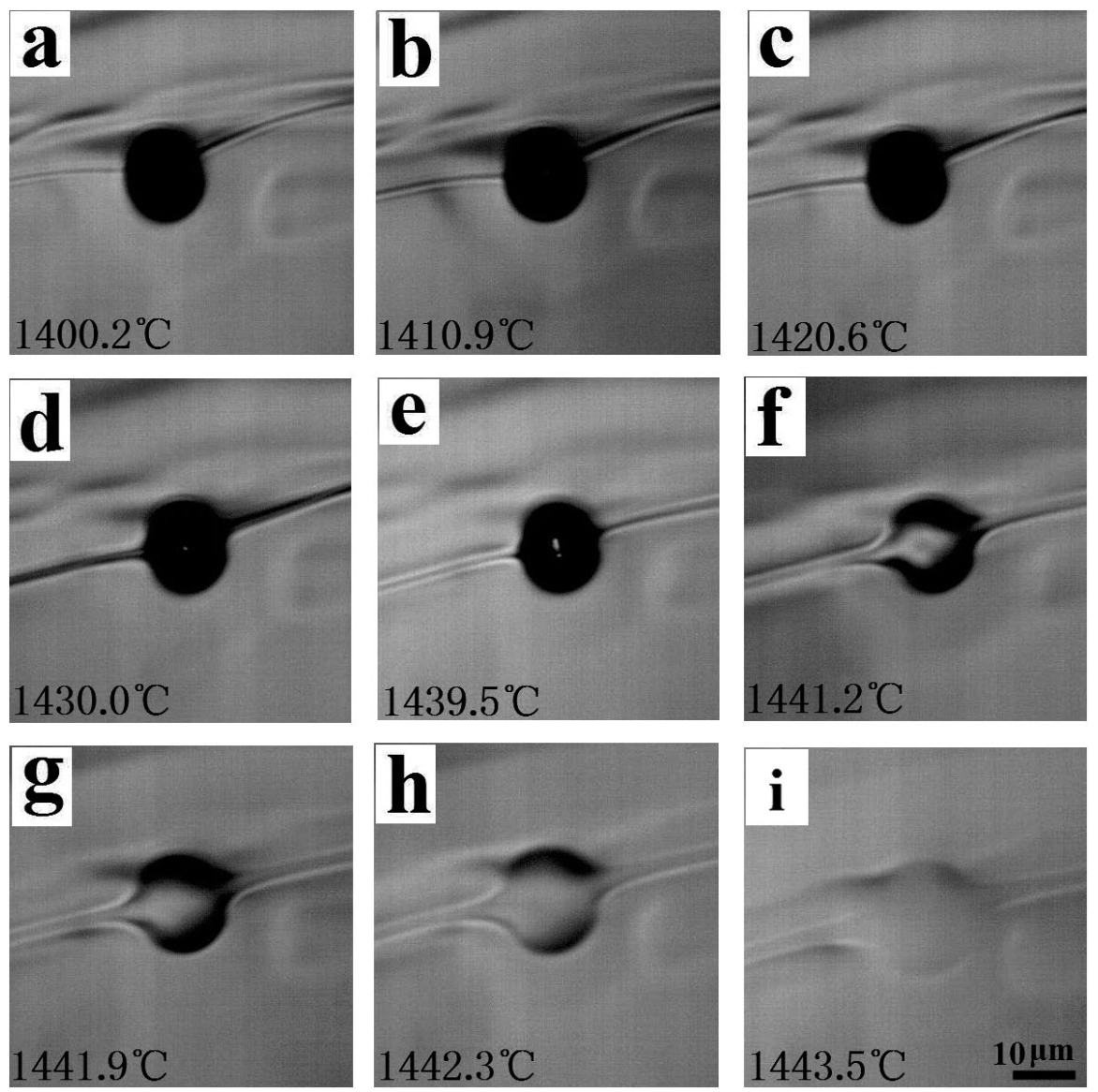

Fig. 9. The evolution of $\mathrm{CaO}-\mathrm{Al}_{2} \mathrm{O}_{3}-\mathrm{SiO}_{2}-\mathrm{MgO}$ inclusion during the process of heating up.

surface. The pit size is a litter larger than the diameter of inclusion, which suggesting the inclusion transform from solid to liquid during the heating up process.

The liquidus temperature and solidus temperature of test steel is $1750 \mathrm{~K}\left(1477^{\circ} \mathrm{C}\right)$ and $1614 \mathrm{~K}\left(1341^{\circ} \mathrm{C}\right)$, and the low-melting-temperature $\mathrm{CaO}-\mathrm{Al}_{2} \mathrm{O}_{3}-\mathrm{SiO}_{2}-\mathrm{MgO}$ inclusion was totally dissolved in steel at $1443.5^{\circ} \mathrm{C}$. It is concluded that this type complex inclusion was dissolved and disappeared completely in solid-liquid two-phase region of the tip of consumable electrode during ESR process. It has been confirmed by many researchers ${ }^{29-31)}$ that most of the inclusions in electrode can be eliminated on the electrode tip-slag interface, and the inclusions detected in the remelted ingot were newly formed in the liquid metal pool during the solidification process. It is considered on the in situ observation experimental results along with analysis that: (i) the inclusions exposed on the electrode tip-slag interface would be eliminated by the continuously slag flow; (ii) since the size of inclusions is much smaller than the thickness of the metal film on the tip of the electrode, a large amount of inclusions cannot be exposed on the electrode tip-slag interface; (iii) the evolution of inclusions during ESR process, which included elimination of inclusions in electrode and formation of new inclusions, might begin on the tip of electrode. Therefore, part of inclusions cannot be removed by slag adsorption, but dissolved in the steel, and some inclusions formed newly in the process of liquid melt film formed on the tip of electrode. Although inclusions dissolved in steel at the tip of the electrode, the T.O content of the remelted ingot was still significant reduced. There- fore, it can be concluded that the decrease of T.O content of remelted ingot was not simply due to the elimination of inclusions, but for the contact of the slag and steel continuously during the ESR process.

The composition of inclusions in each remelted ingot is displayed on the ternary phase diagram, the outer red line region represents $1873 \mathrm{~K}$ and the inner pink line region represents $1773 \mathrm{~K}$. As can be seen in Fig. 10, the inclusions are seemed to exhibit a narrow variation in their compositions distribution of each remelted ingot. Different from the distribution of inclusions in electrode on the ternary phase diagram, most of the inclusions in remelted ingots are located out of the low-melting-temperature region (1 $873 \mathrm{~K})$.

From the observation results of inclusions in remelted ingot, it is confirmed that the inclusions no longer contained $\mathrm{SiO}_{2}$ compared with the inclusions of electrode. The variation of inclusions composition can be attributed to the reaction between $\mathrm{SiO}_{2}$ and dissolved $\mathrm{Al}$ of steel. The reaction is expressed as following: ${ }^{32)}$

$$
\begin{aligned}
& 4[\mathrm{Al}]+3\left(\mathrm{SiO}_{2}\right)_{\text {inclusion }}=3[\mathrm{Si}]+2\left(\mathrm{Al}_{2} \mathrm{O}_{3}\right)_{\text {inclusion }} \text {, } \\
& \Delta \mathrm{G}^{\theta}=-658300+107.2 T(\mathrm{~J} / \mathrm{mol}) \\
& K=\frac{a_{\mathrm{Al}_{2} \mathrm{O}_{3}}^{2} \cdot a_{\mathrm{Si}}^{3}}{a_{\mathrm{SiO}_{2}}^{3} \cdot a_{\mathrm{Al}}^{4}}=\frac{a_{\mathrm{Al}_{2} \mathrm{O}_{3}}^{2} \cdot f_{\mathrm{Si}}^{3} \cdot[\% \mathrm{Si}]^{3}}{a_{\mathrm{SiO}_{2}}^{3} \cdot f_{\mathrm{Al}}^{4} \cdot[\% \mathrm{Al}]^{4}} \\
& \Delta G=\Delta G^{\theta}+\mathrm{R} T \ln K
\end{aligned}
$$

where $\mathrm{R}$ is molar gas constant, the value is $8.314 \mathrm{~J} / \mathrm{mol} \cdot \mathrm{K}$. $\mathrm{T}$ is set as $1873 \mathrm{~K}$. The activity coefficients of [Si] and [Al] are calculated by Eq. (4), the interaction coefficients used in 


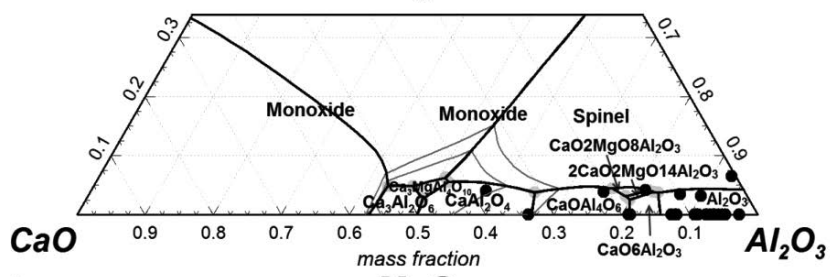

b

MgO

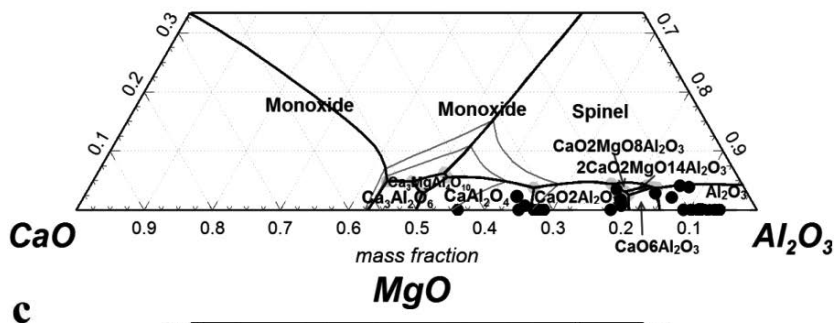

c

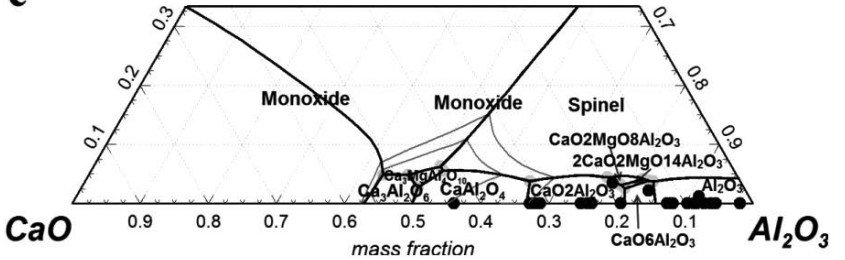

Fig. 10. Distribution of inclusions in the remelted ingots on the ternary $\mathrm{MgO}-\mathrm{CaO}-\mathrm{Al}_{2} \mathrm{O}_{3}$ phase diagram $(\mathrm{K} 1: \mathrm{a} ; \mathrm{K} 2$ : b; $\mathrm{K} 3: \mathrm{c})$.

the current calculation are listed in Table 4. The activities of $\mathrm{Al}_{2} \mathrm{O}_{3}$ and $\mathrm{SiO}_{2}$ at $1873 \mathrm{~K}$ are calculated by FactSage 7.0 according to the steel composition of each electrode and remelted ingot, the results are presented in Table 6. The Gibbs free energy change of reaction (13) is -25.96 , $-26.50,-26.35 \mathrm{~kJ} / \mathrm{mol}$ for the three remelted ingots, which indicates $\mathrm{Al}$ play a role in reducing the content of $\mathrm{SiO}_{2}$ in inclusions. The Gibbs free energy change of reaction (13) for the three electrodes are $-39.25,-39.11,-49.44 \mathrm{~kJ} / \mathrm{mol}$, which are also negative. However, the $\mathrm{SiO}_{2}$ content of inclusions in electrode was very high and reached in the range of $50 \%-80 \%$ as shown in Fig. 2. It indicates that the decrease of $\mathrm{SiO}_{2}$ content of inclusion content cannot be completely attributed to the reduction of $\mathrm{SiO}_{2}$ in the original inclusions by dissolved $\mathrm{Al}$.

The thermodynamic calculation was estimated by FactSage 7.0 with the FactPS, FToxid and FTmisc databases, the content of $\mathrm{Ca}, \mathrm{Mg}$ and $\mathrm{Al}$ were set as $0.0008 \%, 0.0002 \%$ and $0.03 \%$, respectively. The relationship between oxygen content and each component in the liquid phase inclusions of molten steel at $1873 \mathrm{~K}$ was analyzed. The weight percentages of $\mathrm{SiO}_{2}$ in liquid inclusion decrease with the decreasing of oxygen content of steel, as shown in Fig. 11, the $\mathrm{SiO}_{2}$ content in liquid inclusion reaches about $35 \%$ when T.O content of steel is $0.01 \%$. When T.O content of the steel drops to about $0.0015 \%$, liquid inclusions were $\mathrm{CaO}-\mathrm{Al}_{2} \mathrm{O}_{3}$ system containing very small amount of $\mathrm{SiO}_{2}$, which leads to the precipitation of inclusions no longer contained $\mathrm{SiO}_{2}$.

Equilibrium precipitation of inclusions and variation of component in liquid inclusions during solidification of remelted ingot was calculated using FactSage 7.0. As shown in Fig. 12(a), $\mathrm{CaO} \cdot \mathrm{Al}_{2} \mathrm{O}_{3}$ begins to precipitate at around $1460^{\circ} \mathrm{C}$ and keeps on increasing until mass percent reaches $0.003 \%$. And then $\mathrm{CaO} \cdot \mathrm{Al}_{2} \mathrm{O}_{3}$ content decreases correspond-
Table 6. Activities of $\mathrm{Al}_{2} \mathrm{O}_{3}$ and $\mathrm{SiO}_{2}$ at $1873 \mathrm{~K}$ estimated with FactSage 7.0 in each electrode and remelted ingot.

\begin{tabular}{ccl}
\hline number & $\mathrm{SiO}_{2}$ & $\mathrm{Al}_{2} \mathrm{O}_{3}$ \\
\hline $\mathrm{G} 1$ & 0.0063768 & 0.23078 \\
$\mathrm{G} 2$ & 0.0057095 & 0.23078 \\
$\mathrm{G} 3$ & 0.0099837 & 0.23078 \\
$\mathrm{~K} 1$ & 0.0014730 & 0.051454 \\
$\mathrm{~K} 2$ & 0.0020571 & 0.049582 \\
$\mathrm{~K} 3$ & 0.0021381 & 0.032981 \\
\hline
\end{tabular}

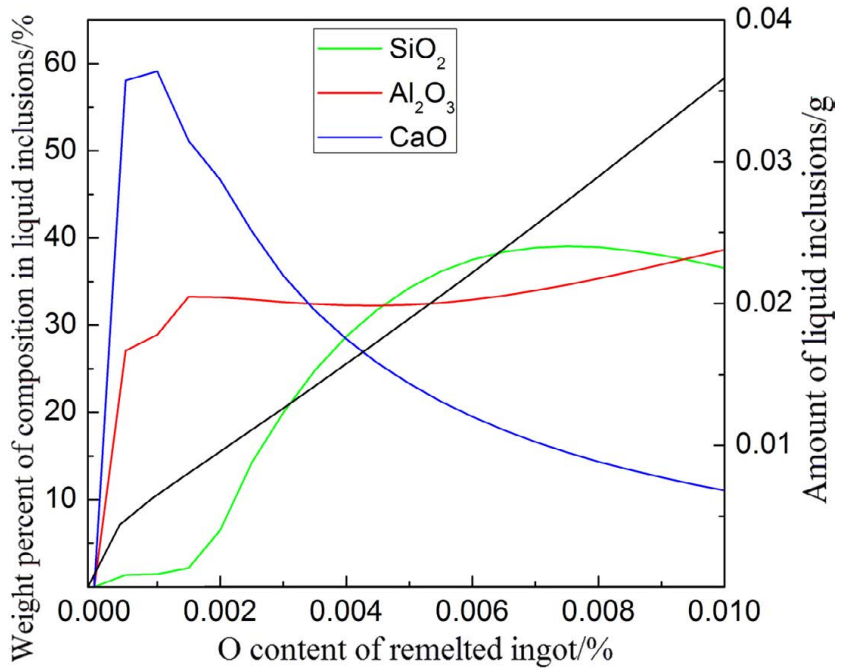

Fig. 11. Relationship between $\mathrm{O}$ content and amount of liquid inclusion and content of each component at $1873 \mathrm{~K}$. (Online version in color.)

ing to the formation of $\mathrm{CaO} \cdot 2 \mathrm{MgO} \cdot 8 \mathrm{Al}_{2} \mathrm{O}_{3}, \mathrm{CaO} \cdot 2 \mathrm{Al}_{2} \mathrm{O}_{3}$ and $\mathrm{CaS}$. The amount of $\mathrm{CaS}$ is $0.0016 \%$ and then remains relatively unchanged. $\mathrm{CaO} \cdot 2 \mathrm{MgO} \cdot 8 \mathrm{Al}_{2} \mathrm{O}_{3}$ has a transition to $2 \mathrm{CaO} \cdot 2 \mathrm{MgO} \cdot 14 \mathrm{Al}_{2} \mathrm{O}_{3}$ around $1070-1230^{\circ} \mathrm{C}$, and $\mathrm{Al}_{2} \mathrm{O}_{3}$ forms after the disappearance of $2 \mathrm{CaO} \cdot 2 \mathrm{MgO} \cdot 14 \mathrm{Al}_{2} \mathrm{O}_{3}$.

It can be seen from the calculation results that $\mathrm{CaO} \cdot 2 \mathrm{MgO} \cdot 8 \mathrm{Al}_{2} \mathrm{O}_{3}, \mathrm{Al}_{2} \mathrm{O}_{3}$ and $\mathrm{CaS}$ would be formed after solidification of the molten steel. However, the thermodynamic calculation of FactSage was based on the Gibbs principle of minimum free energy and equilibrium calculation model. The transition of $2 \mathrm{CaO} \cdot 2 \mathrm{MgO} \cdot 14 \mathrm{Al}_{2} \mathrm{O}_{3}$ cannot take place in actual solidification process due to the poor dynamic conditions at such a low temperature. The formation route of $\mathrm{Al}_{2} \mathrm{O}_{3}$ inclusions is $\mathrm{CaO} \cdot \mathrm{Al}_{2} \mathrm{O}_{3} \rightarrow \mathrm{CaO} \cdot 2 \mathrm{Al}_{2} \mathrm{O}_{3}$ $\rightarrow 2 \mathrm{CaO} \cdot 2 \mathrm{MgO} \cdot 14 \mathrm{Al}_{2} \mathrm{O}_{3} \rightarrow \mathrm{Al}_{2} \mathrm{O}_{3}$ as demonstrated in Fig. 12(a). It is certain that this kind of transformation can hardly happen, which is attributing to the molten steel has already solidified below the solidus temperature. It is concluded that precipitation of $\mathrm{Al}_{2} \mathrm{O}_{3}$ originate from $\mathrm{CaO} \cdot \mathrm{Al}_{2} \mathrm{O}_{3}$ or liquid inclusions at the temperature between the liquidus and the solidus of steel.

Figure 12(b) shows the content variation of inclusions of remelted ingot during the solidification process. As can be seen in the figure, the content of $\mathrm{Al}_{2} \mathrm{O}_{3}$ and $\mathrm{MgO}$ in liquid inclusions gradually increase with the decrease of temperature of molten steel, $\mathrm{CaO}$ content of liquid inclusions gradually decreases. These three components always exist 

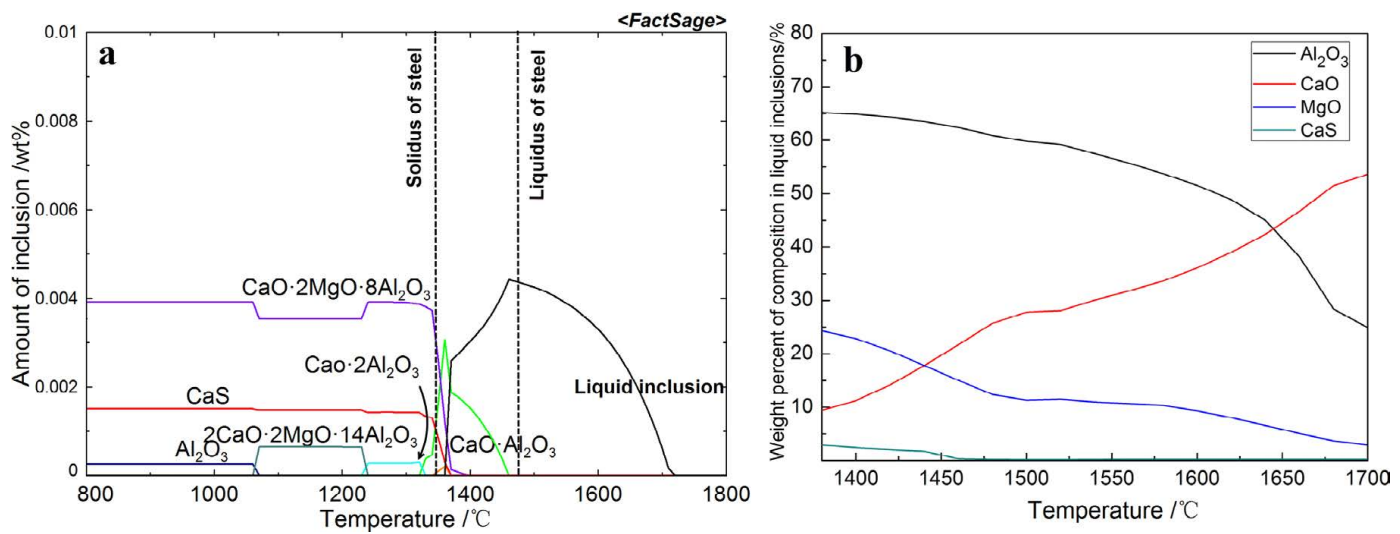

Fig. 12. Equilibrium precipitation of inclusions in remelted ingot during solidification. (Online version in color.)
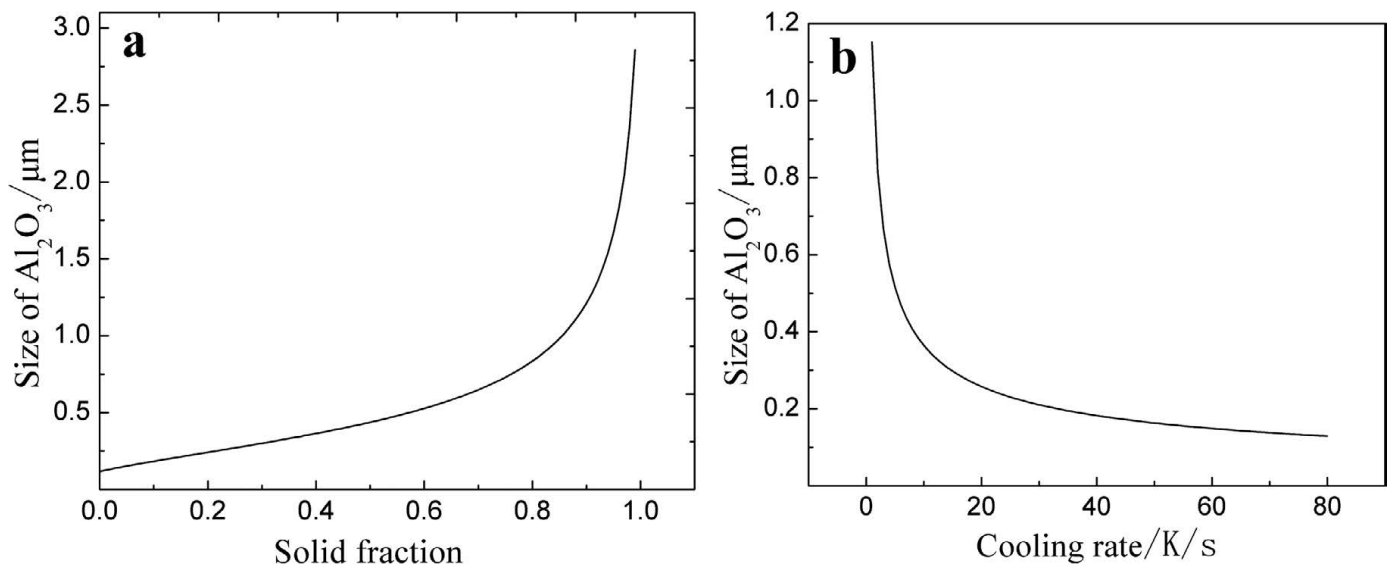

Fig. 13. Relationship between size of $\mathrm{Al}_{2} \mathrm{O}_{3}$ inclusions and solid fraction and cooling rate.

in the liquid inclusions with the variation of temperature, while $\mathrm{CaS}$ is formed at $1470^{\circ} \mathrm{C}$. The content of $\mathrm{Al}_{2} \mathrm{O}_{3}$ in liquid inclusions reaches up to $65 \%$ with the decreasing of temperature, which provides a favorable condition for the precipitation of $\mathrm{Al}_{2} \mathrm{O}_{3}$. The cooling intensity of the edge of remelted ingot is larger than that of the center. Therefore, the component of inclusions in the edge side is closest to the liquid inclusions. The elemental segregation is serious due to the small cooling intensity in the center of remelted ingot. $\mathrm{Al}_{2} \mathrm{O}_{3}$ inclusions were formed in the solid-liquidphase region and further grow up during the solidification.

To clarify the size distribution of $\mathrm{Al}_{2} \mathrm{O}_{3}$ inclusions in different position of remelted ingot, the growth of $\mathrm{Al}_{2} \mathrm{O}_{3}$ inclusions is described by a diffusion-controlled growth model. The $\mathrm{O}$ content is lower than $\mathrm{Al}$ content, consequently the diffusion of oxygen is the limiting factor for the growth of $\mathrm{Al}_{2} \mathrm{O}_{3}$ inclusion. The diffusion growth model of $\mathrm{Al}_{2} \mathrm{O}_{3}$ inclusion during solidification can be expressed by Eq. $(15)^{33)}$

$$
r \frac{d r}{d t}=\frac{M_{s}}{100 M_{m}} \cdot \frac{\rho_{m}}{\rho_{s}} \cdot \mathrm{D}_{\mathrm{O}}\left([\% \mathrm{O}]-[\% \mathrm{O}]_{e}\right)
$$

where, $r$ is $\mathrm{Al}_{2} \mathrm{O}_{3}$ radius, $\mathrm{m} . t$ is the time for $\mathrm{Al}_{2} \mathrm{O}_{3}$ growth, $\mathrm{s}, M_{m}$ is molar mass of liquid steel, $0.056 \mathrm{~kg} \cdot \mathrm{mol}^{-1}, M_{s}$ is molar mass of $\mathrm{Al}_{2} \mathrm{O}_{3}, 0.102 \mathrm{~kg} \cdot \mathrm{mol}^{-1}, \rho_{\mathrm{m}}$ is density of liquid steel, $7.6 \times 10^{3} \mathrm{~kg} \cdot \mathrm{m}^{-3} ; \rho_{\mathrm{s}}$ is density of $\mathrm{Al}_{2} \mathrm{O}_{3}, 3.97 \times 10^{3}$ $\mathrm{kg} \cdot \mathrm{m}^{-3} ; \mathrm{D}_{\mathrm{O}}$ is the diffusion coefficient of $\mathrm{O}$ in liquid steel, $\mathrm{m}^{2} \cdot \mathrm{s}^{-1} ;[\% \mathrm{O}]$ is concentration of $\mathrm{O}$ in solidification front, $[\% \mathrm{O}] \mathrm{e}$ is equilibrium concentration.

The growth of $\mathrm{Al}_{2} \mathrm{O}_{3}$ inclusions during solidification can
Table 7. Equilibrium partition coefficients $k$ of $\mathrm{O}$ between solid and liquid and the diffusion coefficients $D_{\mathrm{L}}{ }^{34)}$

\begin{tabular}{cccc}
\hline Element & $\mathrm{k}$ & $\mathrm{D}_{\mathrm{S}} /\left(\mathrm{cm}^{2} \cdot \mathrm{s}^{-1}\right)$ & $\mathrm{D}_{\mathrm{L}} /\left(\mathrm{cm}^{2} \cdot \mathrm{s}^{-1}\right)$ \\
\hline $\mathrm{O}$ & 0.022 & $0.0371[\exp (-96349 / \mathrm{RT})]$ & $1.2 \times 10^{-4}$ \\
\hline
\end{tabular}

be obtained by Eqs. (16) and (17).

$$
\begin{array}{r}
r=\sqrt{\frac{M_{s}}{50 M_{m}} \cdot \frac{\rho_{m}}{\rho_{s}} \cdot \mathrm{D}_{\mathrm{O}}\left([\% \mathrm{O}]-[\% \mathrm{O}]_{e}\right) t} \\
t=\left[1-f(t)_{e}\right] \tau \ldots \ldots \ldots \ldots \ldots \ldots \ldots \ldots \ldots \ldots \ldots
\end{array}
$$

where $t$ is the local growth time (s) and $f(\mathrm{t})_{\mathrm{e}}$ is the solid fraction of molten steel when $\mathrm{Al}_{2} \mathrm{O}_{3}$ precipitates. Since $\mathrm{Al}_{2} \mathrm{O}_{3}$ is formed in the liquid phase, the local growth time and the local solidification time $\tau$ are equal. The size of $\mathrm{Al}_{2} \mathrm{O}_{3}$ can be calculated based on Eq. (18).

$$
r=\sqrt{\frac{M_{s}}{50 M_{m}} \cdot \frac{\rho_{m}}{\rho_{s}} \cdot \mathrm{D}_{\mathrm{O}}\left([\% \mathrm{O}]-[\% \mathrm{O}]_{e}\right) \cdot \frac{T_{\mathrm{L}}-T_{\mathrm{S}}}{R_{\mathrm{C}}}} \ldots
$$

It is obvious from Eq. (18) that the radius of $\mathrm{Al}_{2} \mathrm{O}_{3}$ inclusion is greatly affected by the cooling rate and $[\% \mathrm{O}]$ of steel. The Fig. 13(a) illustrates the calculation result of variations of the size of $\mathrm{Al}_{2} \mathrm{O}_{3}$ inclusions during solidification, the size of $\mathrm{Al}_{2} \mathrm{O}_{3}$ inclusions gradually increase with the increasing of solid fraction.

Figure 13(b) shows the relation between $\mathrm{Al}_{2} \mathrm{O}_{3}$ and cooling rate. It can be derived from Fig. 13(b) that the precipi- 
tate size of $\mathrm{Al}_{2} \mathrm{O}_{3}$ inclusion decreases with the increasing of cooling rate. The cooling intensity of the edge side of the remelted ingot is larger than the center and the local growth time of $\mathrm{Al}_{2} \mathrm{O}_{3}$ inclusion is short, which is resulting in the precipitate size of $\mathrm{Al}_{2} \mathrm{O}_{3}$ inclusions on the edge side is smaller than those in the center. It is concluded that the detection of more tiny size $\mathrm{Al}_{2} \mathrm{O}_{3}$ inclusions at the edge of the remelted ingot is due to the different growth time of $\mathrm{Al}_{2} \mathrm{O}_{3}$ at different position of remelted ingot.

\section{Conclusions}

The H13 steel consumable electrodes with different $\mathrm{Ca}$ content refined through ESR were carried out to investigate the formation and modification of inclusions during ESR process. The compositional evolution mechanism of oxide and sulfide inclusions was proposed on the basis of laboratory experiment and thermodynamic calculations. The following conclusions were obtained:

(1) The typical inclusions in three consumable electrodes were $\mathrm{CaO}-\mathrm{Al}_{2} \mathrm{O}_{3}-\mathrm{SiO}_{2}-\mathrm{MgO}$, meanwhile, $\mathrm{MnS}$ and $\mathrm{CrS}$ can be detected occasionally on the edge of inclusions. Most of the oxide inclusions in electrodes were located in the $1600^{\circ} \mathrm{C}$ liquid region, and the melting temperature of inclusions decreased with the increasing of $\mathrm{Ca}$ content of steel.

(2) The inclusions were $\mathrm{Al}_{2} \mathrm{O}_{3}, \mathrm{CaO}-\mathrm{Al}_{2} \mathrm{O}_{3}$ and $\mathrm{CaO}-$ $\mathrm{MgO}-\mathrm{Al}_{2} \mathrm{O}_{3}$ in all the remelted ingots after ESR process, $\mathrm{MnS}$ and $\mathrm{CrS}$ were eliminated totally. More than $50 \%$ of the inclusions in the remelted ingots were $3 \mu \mathrm{m}$ or less, and the amount of $\mathrm{Al}_{2} \mathrm{O}_{3}$ inclusions took up about $70 \%$ of the total inclusions. The different of $\mathrm{Ca}$ content in electrodes had no effect on the size distribution of inclusions in remelted ingots.

(3) MnS began to precipitate in the consumable electrode when solid fraction reached 0.98 . The calculation results reveal that the formation of $\mathrm{MnS}$ inclusions in the electrode is ascribed to the micro segregation of $\mathrm{Mn}$ and $\mathrm{S}$ during the solidification process. Since the solidification during ESR process is rapid, MnS formation could not take place in the solidification process of remelted ingots.

(4) The low-melting-temperature inclusions in consumable electrode began to dissolve approximately at a temperature of $1430.0^{\circ} \mathrm{C}$, and disappeared completely after solidliquid two-phase region of the tip of consumable electrode was formed at $1443.5^{\circ} \mathrm{C}$ during ESR process.

(5) The inclusions in remelted ingots were located out of the $1600^{\circ} \mathrm{C}$ low-melting-temperature region. The oxygen content of steel decreased from $0.01 \%$ to around $0.0015 \%$ after ESR process, which caused the low-level oxygen content in the liquid melt pool. The decreasing of oxygen content in liquid melt pool resulted in the reduce of $\mathrm{SiO}_{2}$ content in liquid inclusions, which contributed to the elimination of $\mathrm{SiO}_{2}$ from original complex inclusions of consumable electrode.

(6) The $\mathrm{Al}_{2} \mathrm{O}_{3}$ content of liquid inclusions increased to about $65 \%$ when the steel temperature decreased to $1400^{\circ} \mathrm{C}$ according to the calculation results by FactSage, which resulted in the large amount of $\mathrm{Al}_{2} \mathrm{O}_{3}$ inclusions formed in the remelted ingots. The cooling intensity in the edge side of remelted ingot is the largest, the harder cooling intensity leads to the decrease of $\mathrm{Al}_{2} \mathrm{O}_{3}$ size because higher cooling rate makes the time for $\mathrm{Al}_{2} \mathrm{O}_{3}$ growth shorter.

\section{Acknowledgments}

The financial support by the National Natural Science Foundation of China (Grant Nos. 51504019 and 51874026), and the National Key Research and Development Program of China (Grant No. 2016YFB0300604) is greatly acknowledged.

\section{REFERENCES}

1) N. Ballal, G. Goldhahn and R. Kawalla: ISIJ Int., 49 (2009), 902.

2) C. B. Shi, X. C. Chen, H. J. Guo, Z. J. Zhu and H. Ren: Steel Res. Int., 83 (2012), 472.

3) J. H. Liu, G. X. Wang, Y. P. Bao, Y. Yan, Y. Wei and X. N. Gui: J. Iron Steel Res. Int., 19 (2012), 1.

4) X. C. Chen, C. B. Shi, H. J. Guo, F. Wan, H. Ren and D. Feng: Metall. Mater. Trans. B, 43 (2012), 1596.

5) D. P. Zhan, Y. P. Zhang, R. J. Liu, Z. H. Jiang and H. S. Zhang: Ironmaking Steelmaking, 44 (2017), 368.

6) G. Du, J. Li and Z. B. Wang: ISIJ Int., 58 (2018), 78.

7) Y. W. Dong, Z. H. Jiang, Y. L. Cao, A. Yu and D. Hou: Metall. Mater. Trans. B, 45 (2014), 1315.

8) D. W. Zhao, H. B. Li, C. L. Bao and J. Yang: ISIJ Int., 55 (2015), 2115 .

9) J. F. Xu, F. X. Huang and X. H. Wang: Metall. Mater. Trans. B, 47 (2016), 1217.

10) J. Fu and J. Zhu: Acta Metall. Sin., 7 (1964), 250.

11) Y. W. Dong, Z. H. Jiang and A. Yu: Metals, 6 (2016), 273.

12) Y. Liu, Z. Zhang, G. Q. Li, Q. Wang, L. Wang and B. K. Li: Steel Res. Int., 88 (2017), 1700058.

13) H. Y. Mu, T. S. Zhang, L. Yang, R. R. Xavier, R. J. Fruehan and B. A. Webler: Metall. Mater. Trans. B, 47 (2016), 3375.

14) J. Guo, S. S. Cheng and Z. J. Cheng: ISIJ Int., 53 (2013), 2142.

15) L. Z. Kong, Z. Y. Deng and M. Y. Zhu: ISIJ Int., 57 (2017), 1537.

16) W. Yang, L. F. Zhang, X. H. Wang, R. Ying, X. F. Liu and Q. L. Shan: ISIJ Int., 53 (2013), 1401.

17) C. B. Shi, X. C. Chen, H. J. Guo, Z. J. Zhu and X. L. Sun: Metall. Mater. Trans. B, 44 (2013), 378.

18) S. F. Yang, Q. Q. Wang, L. F. Zhang, J. S. Li and K. Peaslee: Metall. Mater. Trans. B, 43 (2012), 731.

19) Y. Tabatabaei, K. S. Coley, G. A. Irons and S. Sun: Metall. Mater. Trans. B, 49 (2017), 375.

20) Y. Ueshima, K. Isobe, S. Mizoguchi, H. Maede and H. Kajioka: Tetsu-to-Hagané, 74 (1988), 465 (in Japanese).

21) C. H. P. Lupis: Chemical Thermodynamics of Materials, Elsevier Science Publishing Co. Inc., New York, (1983), 581.

22) P. J. Chen, C. Y. Zhu, G. Q. Li, Y. W. Dong and Z. C. Zhang: ISIJ Int., 57 (2017), 1019.

23) G. K. Sigworth and J. F. Elliott: Met. Sci., 8 (1974), 298.

24) M. Suzuki, R. Yamaguchi, K. Murakami and M. Nakada: ISIJ Int., 41 (2001), 247.

25) Y. M. Won and B. G. Thomas: Metall. Mater. Trans. A, 32 (2001), 1755 .

26) J. Matsuno: Proc. Symp. Solidification Phenomena, Solidification Comm., ISIJ, Tokyo, (1976), 2.

27) X. H. Huang: The Principle of Ferrous Metallurgy, 4th ed., Metallurgical Industry Press, Beijing, (2005), 181 (in Chinese).

28) S. K. Choudhary and A. Ghosh: ISIJ Int., 49 (2009), 1819.

29) A. Mitchell: Ironmaking Steelmaking, 1 (1974), 172.

30) A. Sawahata, H. Tanigawa and M. Enomoto: J. Jpn. Inst. Met., 72 (2008), 176.

31) D. A. R. Kay and R. J. Pomfret: J. Iron Steel Inst., 209 (1971), 962.

32) H. Ohta and H. Suito: Metall. Mater. Trans. B, 27 (1996), 943.

33) H. Goto, K. Miyazawa, Y. Wataru and K. Tanaka: ISIJ Int., 35 (1995), 708.

34) J. Y. Li, G. G. Cheng, L. Y. Li, B. Hu, C. S. Xu and G. M. Wang: Steel Res. Int., 89 (2018), 1700461. 